\title{
Optimization of Agriculture Land Use Development Basing on Natural-resource Potential (On the Example of the Stavropol Territory)
}

\section{E V Pismennaya, V A Stukalo, I A Volters, M Yu Azarova, V M Perederieva, and V I Faizova}

Department of agrobiology and land resources, Stavropol State Agrarian University, Stavropol, Russia

\section{Abstract}

Natural resources potential of the territory and natural-historical mechanism of its development are pacing factors in agriculture differentiation and AIC-development. Key branches in the Stavropol Territory are crop production, sheep breeding and meat and milk cattle breeding. To meet the market demands "equating" differentiation of agricultural enterprises is implemented. Thus, in Stavropol Territory crop lands have

Corresponding Author:

E V Pismennaya

pismennaya.elena@bk.ru

Received: 25 October 2019

Accepted: 15 November 2019

Published: 25 November 2019

Publishing services provided by Knowledge E

(c) E V Pismennaya et al. This article is distributed under the terms of the Creative Commons Attribution License, which permits unrestricted use and redistribution provided that the original author and source are credited.

Selection and Peer-review under the responsibility of the AgroSMART 2019 Conference Committee. been increased for crops required in the market that disbalanced the crop rotation, disturbed agro technologies and resulted in reduction in yields and grain quality. In the Territory $70 \%$ of tillage is in risky agriculture. About $65 \%$ of crop production (wheat, barley and others) are in draughty areas where out of 141 years (1861--2002) $41 \%$ draughty, which determine high natural-climatic dependence of grain economy [1]. Annual and areal variability of grain production is also determined by topsoil heterogeneity and variety of relief. At present production of the basic market crop -- winter wheat, which takes $75 \%$ of acreage for cereals and leguminous crops, the productivity of the cultivated crop is $22.4-39.5$ centner/hectare. It results in top soil changes such as compaction, fertilizer impoverishment and organic matter content (organic matter deficit is $400--700 \mathrm{~kg} / \mathrm{ha}$ ). Intensification of agrarian production results in quicker erosion processes, soil properties decline and lower fertility. The total area of eroded lands in the Territory is 1792000 ha [2]. That is why it is important to develop a new model of the economic use of Stavropol Territory. The main methods of study are analysis of the current status and organization of the agricultural zones of the Territory. The data were preceded with the software Statistica.

\section{Introduction}

With changes in the global political and economical situation management of the land use becomes acute. Taking into account the development of the market, dominance of big agro enterprises, diversity of agro ecological conditions, ecologization of the activity becomes acute as well as its diversification according to natural, edaphoclimatic and landscape conditions, adaptation to economical and social market parameters. Thus, at 
self-sustainability of Stavropol farms and state subsidizing the economic interest arises to maximal utilization of land potential. Preservation and reproduction of their fertility, protection against depletion and degradation receive little attention [3]. That is why when solving strategic, planned and current issues on AIC maintenance at all interregional hierarchical levels of land-use a natural potential of the complex (farm), market performance (demand, type, and volume of production) should be taken into account, and finally at the last stage of managing decision making -- production programmes of the enterprise [4].

Today market conditions undermined scientific grounds of the crop production economy [5]. In the Stavropol Territory the cropped lands in all agricultural zones are mostly taken by crops demanded at the market which increases disbalance in biological structure of crop rotation. The basic commercial crop -- winter wheat -- is being placed after not the best fore crops that resulted in the crop yield decrease and worse grain quality. Non-tested agro technologies are being used in some zones. Limited financing do not allow using mineral fertilizers and ameliorants in scientifically grounded amounts. Long-term refusal to use them results in diminishing soil fertility and productivity. There is also a growing tendency in unfavorable natural phenomena. Today the area of eroded agricultural lands is 3926643 ha. Soil drifting and erosion are main factors of dehumification. [6]. Combination of factors has a negative impact on land farming and cattle breeding and results in their instability.

\section{Materials and Methods}

Issues of planning and rational use of natural resource potential of agrarian territories are described in the works of Russian and foreign scientists [7--10]. Issues of ecological agriculture management and maintenance are also studied by the scientific society [11--14].

Generalization of the scientific experience in the sphere of sustainable land-use and ecologization of process intensification is in the following scientific works [15--19].

But, these studies have a general character and a more detailed research is necessary for developing new models of practical use of agriculture zones in Stavropol Territory.

Sustainable land use and optimal crop growing are determined according to climate agricultural efficiency across agro climatic and soil of the Territory by 28 parameters. To estimate the environmental organization of the territory the parameters of the area ecological stability are determined. The record of natural-resources potential of the area (potential, climatic and really possible land productivity) by soil-climatic zones of 
the territory allowed optimizing the cultivated land of crops (SYcl), and introduced by the formula:

$$
S Y c l=f(a, b, c),
$$

where $a$ is the block of natural-climatic parameters; $b$ is the block of agro-ecological parameters; $c$ is economical block of parameters

\section{Results and Discussions}

\subsection{Structural-functional development model of the Stavropol Ter- ritory}

The Stavropol Territory from 1955 to the beginning of 90th XX century was a grain and sheep breeding zone with the developed grain production (mostly winter grain), cattle and poultry breeding. The highest economical effect was in 1980--1985. Further economic transformations made significant corrections into the economic parameters of the zone specification: the territory becomes a crop growing territory. The effect of crop growing decreases nowadays. Crop share in cultivated lands is $71.3 \%$. Absence of state agrarian strategy for the last 20 years resulted in loss ratio of cattle breeding and some agricultural segments of industry (grass cropping, forage production and so on). On the whole the economical situation in the area is in crisis: "subsidized survival" without the account of ecologic-economical potential of the territory [19]. Present day market performance disputes investment profitability in the nearest future even into plant cropping due to climatic changes, soil and ecological conditions, periodic aggravation of erosion and soil drifting as well as state policy on grain export and tendencies in price rise at the domestic market.

The key factor of the production sustainability is developing a rational structure of crop lands, its compliance with social demands in plant-growing products and raw materials (including forage) and scientifically grounded crop rotation. It is recommended to reduce tillage area on the Territory by $13.0 \%$ from the existing one (or by $0.5 \mathrm{mln}$ ha), which will make $3.4 \mathrm{mln}$ ha on the whole on the territory, and reduce the crop area on the total in the Territory from 75.0 (2017) to 60.9 \% (from 2.3 to $1.7 \mathrm{mln}$ ha) (table. 1).

It is recommended to occupy by technical crops 398.3 thousands of ha, potatoes, vegetables, gourd -- 94.2 thousands of ha and forage -- 607.8 thousands ha. At this crop rotation the grain economy has priority in all agricultural zones with those branches and crops which have better natural-climatic, soil and orographic conditions. The projected 
area of the complete fallow will decrease and make 422.9 thousands ha (or $37.6 \%$ of the winter wheat area).

Due to weather and climate changes deterioration of conditions (in water supply) in row crop production is expected, so it is recommended to reduce them in crop rotation from 8.4 to $7.5 \%$ due to temperature increase, short rainfall, increase in return period of estivo-autumnal droughts [3].

To rehabilitate cattle farming it is necessary to optimize the areas and structure of crops (grain-fodder and forage). Analysis of agro-ecological parameters of 6 groups of lands showed that IV, V and VI groups of lands are a reserve for hay-making and cattle run. If the area of fodder-producing areas is $2.06 \mathrm{mln}$ ha, crop yield is 0.8 tons of fodder units, the volume of production is $1.6 \mathrm{mln}$ tons of fodder units. The tillage $0.60 \mathrm{mln}$ ha and crop yield 3.0 tons of fodder units gives the volume of production $1.8 \mathrm{mln}$ tons of fodder units. Total livestock numbers can be $0.9 \mathrm{mln}$ heads.

TABLE 1: Recommended areas of crop lands in all agricultural zones in the Stavropol Territory, thousands ha.

\begin{tabular}{|c|c|c|c|c|c|c|c|c|}
\hline \multirow{3}{*}{ Agricultural crops } & \multicolumn{8}{|c|}{ Agricultural zones } \\
\hline & \multicolumn{2}{|c|}{1} & \multicolumn{2}{|c|}{ ॥ } & \multicolumn{2}{|c|}{ III } & \multicolumn{2}{|c|}{ IV } \\
\hline & $\mathrm{F}$ & $P$ & $\mathrm{~F}$ & $\mathrm{P}$ & $\mathrm{F}$ & $P$ & $\mathrm{~F}$ & $P$ \\
\hline \multirow{5}{*}{$\begin{array}{l}\text { Cropped area, } \\
\text { total including } \\
\text { technical crops, } \\
\text { potato, } \\
\text { vegetables, gourd } \\
\text { field, forage }\end{array}$} & 539.1 & 513.5 & 1112.3 & 921.6 & 927.4 & 891.7 & 388.1 & 294.1 \\
\hline & 440.6 & 326.3 & 921.6 & 835.4 & 630.5 & 531.0 & 278.9 & 156.6 \\
\hline & 25.1 & 19.0 & 181.7 & 150.7 & 223.9 & 171.3 & 83.7 & 48.5 \\
\hline & 12.5 & 19.0 & 17.1 & 23.9 & 200 & 22.8 & 12.6 & 14.1 \\
\hline & 60.9 & 149.2 & 58.2 & 102.3 & 53.0 & 166.6 & 12.9 & 74.9 \\
\hline
\end{tabular}

Note: F-- fact (2017), P -- project.

Though the ration of tillage and fodder areas will not change significantly (factual -66:28, planned -- 55:33), the increase of fodder areas in all agricultural areas (in I zone -- by 1.10 times (from 44.7 to $49.7 \%$ ), in II zone -- by 1.43 times (from 25.4 to $31.4 \%$ ), in III zone -- by 1.13 times (from 23.6 to 30.1 \%), in IV zone -- by 1.11 times (from 19.3 to $21.4 \%)$ ), will perpetuate agrocoenoses. The ecological stability index of the area will increase from 0.18 to 0.20 and by agro zones: in I zone -- from 0.21 to 0.24 , in the II zone -- from 0.17 to 0.20 , in III zone -- from 0.18 to 0.20 , in IV zone -- from 0.14 to 0.15 , that will evidence improvement of interrelation of natural resources potential of the land utilization and economical capacity. 


\subsection{Structural-functional attributive development model of agri- cultural zones in the Stavropol Territory}

To avoid further sectorial imbalance it is recommended in all agricultural zones of the Territory to prevent the prioritized development of the grain economy in combination with other branches (sub-branches) and agricultural crops. To rehabilitate cattle breeding it is reasonable to increase the area of forage crops from $21.6 \%$ (607.8 thousands ha) from planting acreage and cattle runs to $33 \%$ of planting acreage ( $2.06 \mathrm{mln}$ ha); to conduct radical and simplificated improvement of the area correspondingly 807.2 (46.7\% of agricultural lands) and 81.6 thousands of ha (4.7\%).

The first zone -- a recommended specialization: sheep-breeding, grain-sheep breeding and sheep-breeding-grain. Potato and vegetable production on the irrigated zones is recommended, as well as perennial grass. It is recommended to link the zone specialization production types of farming with seeding structures (Figure 1).

According to calculations the total planting acreage should be reduced by 25.6 thousands ha (or by $4.7 \%$ ). The main commercial crop remains winter wheat which will occupy $56.2 \%$ of planting acreage. The main part of winter wheat is in a fallow short rotation (without cultivated crops). Forage crops will occupy $29.1 \%$ of the territory. The most important organizational measure is reduction of complete fallow areas to 245.2 thousands of ha.

In cattle breeding it is better to keep conventional organization and technology of commercial sheep breeding -- pasture one, and use new ones -- stall-pasture, pasturestall, and pasture-semi stall due to forage production from tillable lands.

Close attention in land organization system should be paid to the creation of anti erosion measures -- afforestation belts formation.

The second zone is recommended for grain-sheep breeding. It is recommended to produce potato, vegetables, and cucurbits, fruit growing and wine growing. It is recommended to reduce the crop area by 79.5 thousand ha (or by $6.7 \%$ ). The recommended structure of the acreage is in Figure 2. The leading crop is winter wheat, the area of which will reduce up to $43.9 \%$. The reduction of crop saturation in crop rotation is caused by the combination of the broken ground with the hot winds, that causes wind and water erosion. Besides, it is necessary to reduce complete fallow areas to 161.3 thousand ha (or by $32.9 \%$ ). To rehabilitate cattle breeding it is necessary to provide sufficient forage (green forage chain). That is why projected area for forage crops is 102.3 thousand ha (increased by 1.8 times in comparison with factual). 


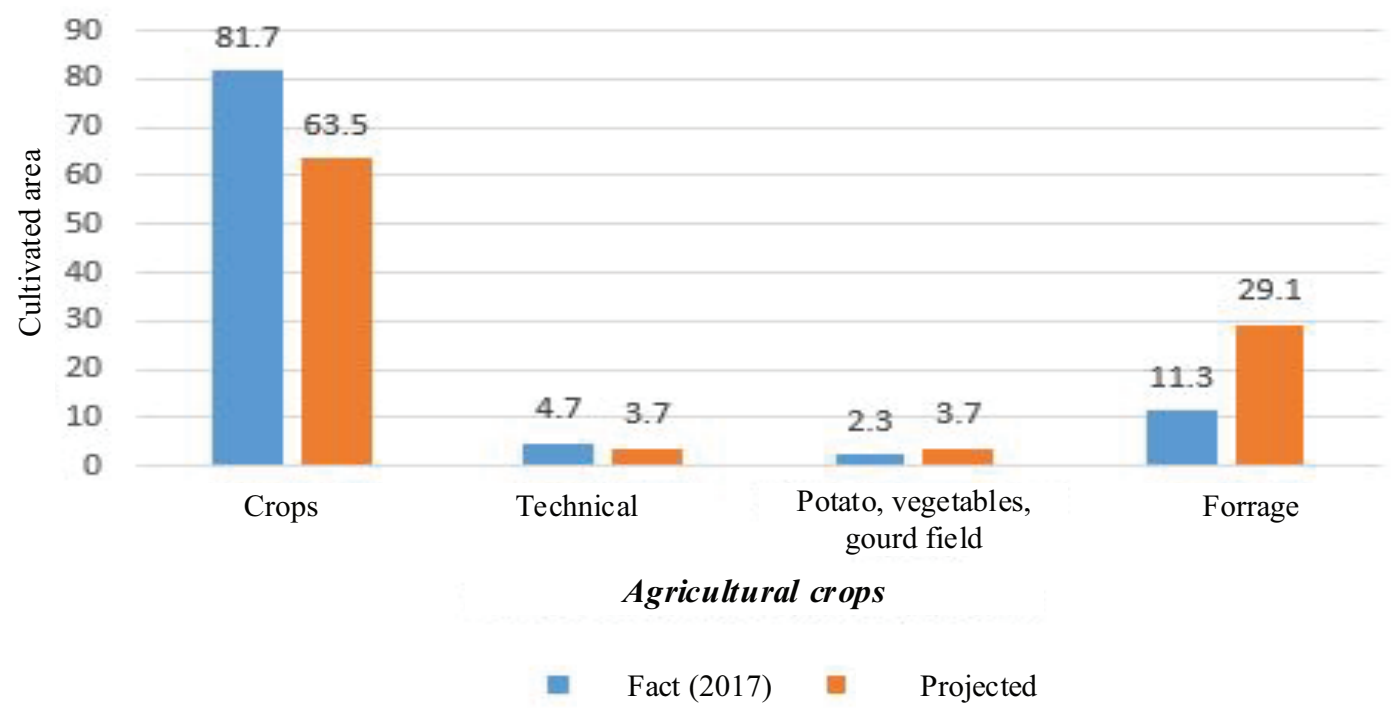

Figure 1: Recommended structure of crop areas of the I agricultural zone.

Consequently, the main way to overcome branch contradictions on the area is interzonal specialization of agricultural enterprises, and full development of rational cropping system (grain-fallow-tillage and grain-fallow), system development of farm management.

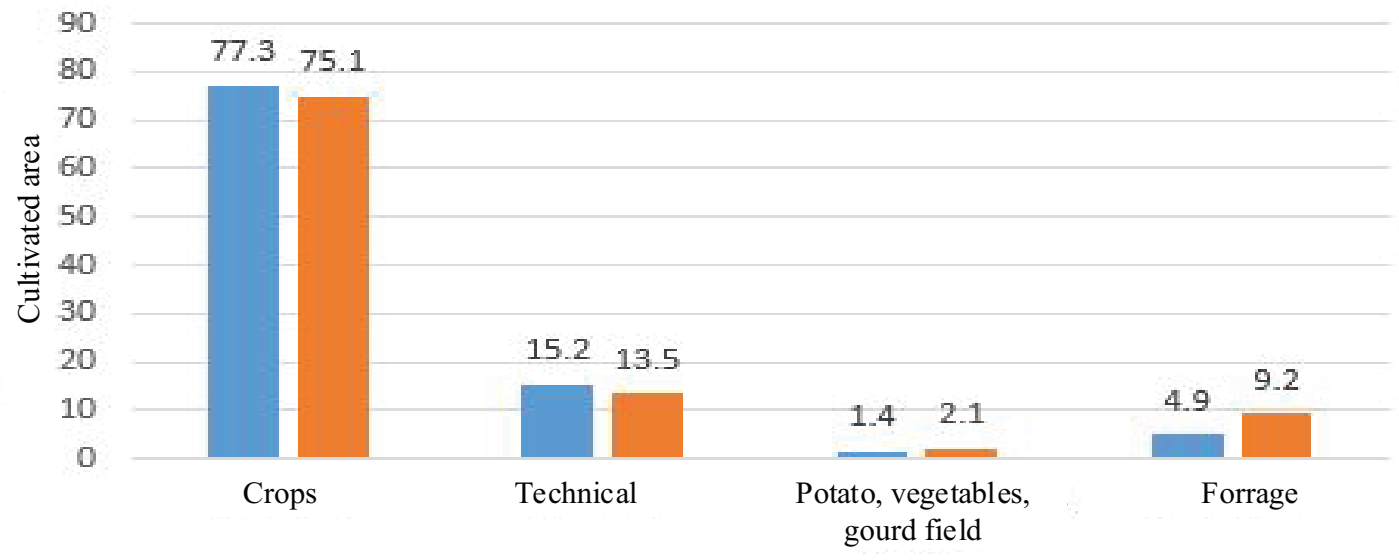

Agricultural crops

- Fact (2017) - $\quad$ Projected

Figure 2: The recommended structure of the cropping pattern of the II agricultural zones.

The third zone -- recommended specialization is grain-cattle-breeding. It is recommended to develop plant crop growing and fruit growing, formation of diversified agroenterprises. The recommended structure of cropping pattern is in Figure 3. The total area of crops will be reduced by 35.7 thousands of ha (or by $3.8 \%$ ). The main commercial crop is winter wheat which will occupy $36.7 \%$ of the cropping area. 


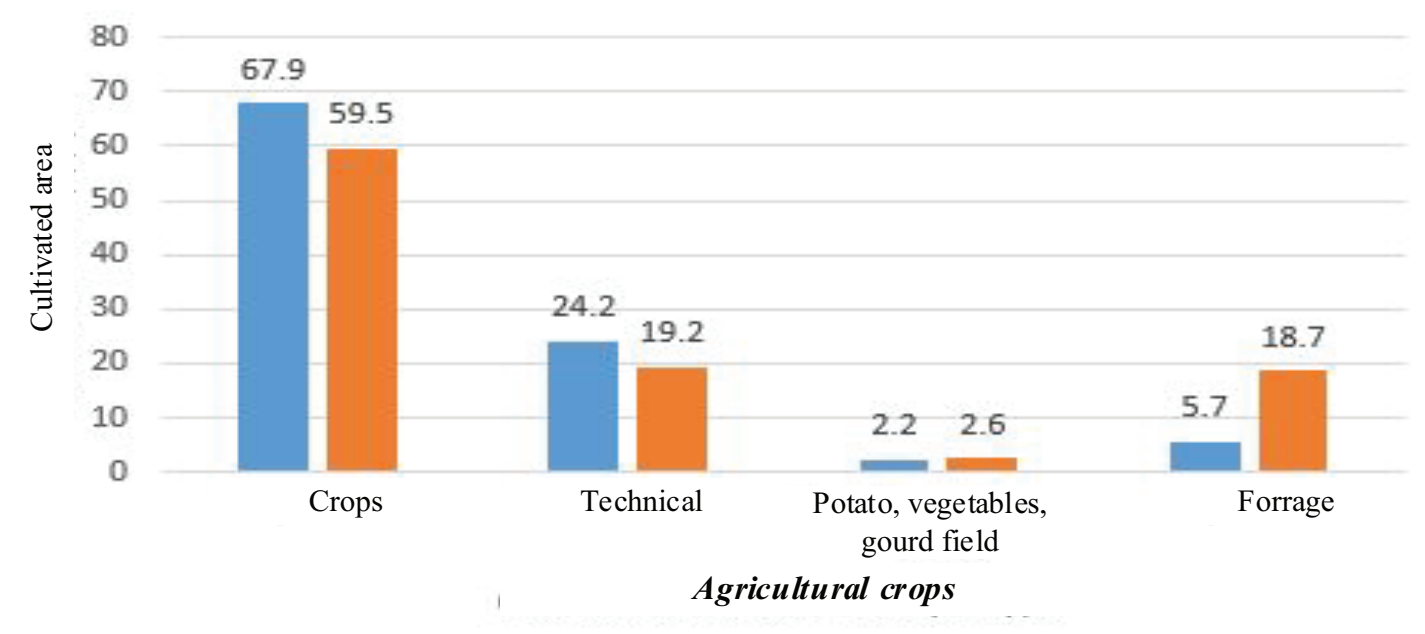

Fact (2017) $\quad$ Projected

Figure 3: The recommended structure of the cropping pattern of the II agricultural zones.

In agro-enterprises it is necessary to use diversified land use (grain-fallow-tillage, grain-tillage, grain-grass, grain-grass-tillage and others) with different level of branch development. In these farms the prime cost of technical crops growing will be higher, than in all farms of the Territory. The combination of the broken ground with dry winds in steeps results in blowing erosion and soil erosion. It is rational to reduce the area of these crops production.

Tillage system in steeps should meet the requirements of the soil-protecting one. Forest belts are broken up and need reconstruction and further rehabilitation.

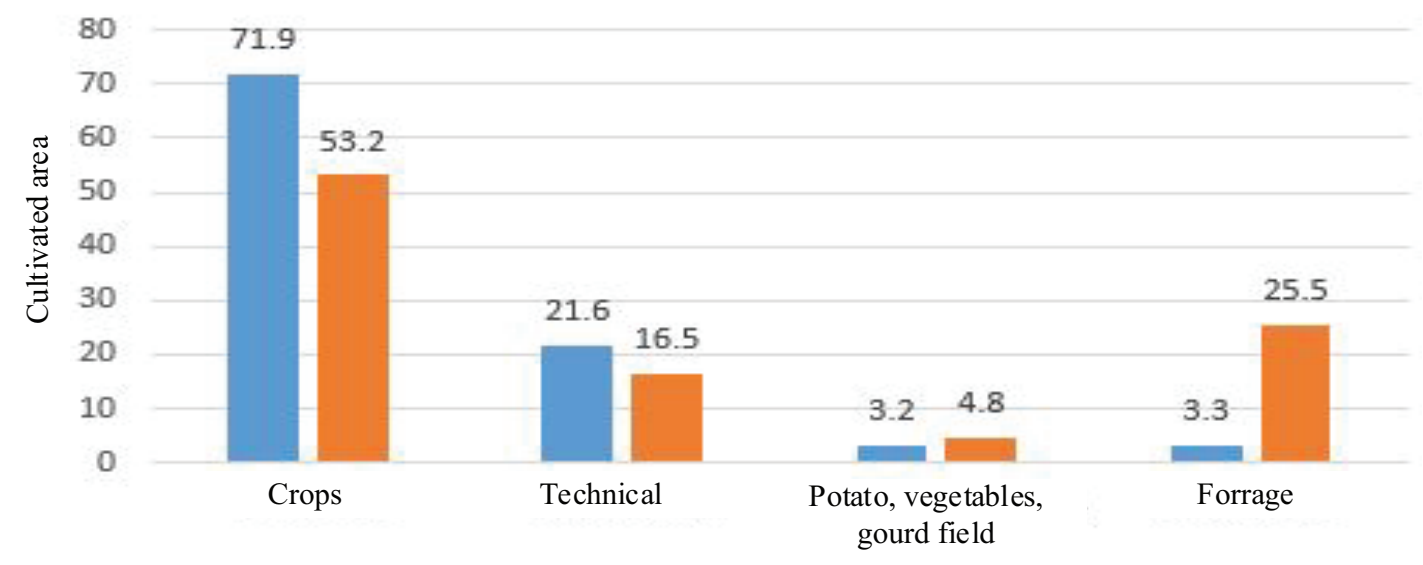

Agricultural crops

Fact (2017) , Projected

Figure 4: The recommended structure of the cropping pattern of the IV agricultural zones. 
The fourth zone is a recommended resort area. It is rational to develop intensive branches and farms of different industrial types to meet the population needs in cities and resorts in low-transportable and perishable food. It is recommended to reduce the planting acreage by 94.0 thousands of ha (or by $24.2 \%$ ). The recommended structure of the planting acreage is in Figure 4. It is necessary to preserve diversified type of agro-enterprises (fruit-growing, vegetable-growing, cattle breeding and so on).

In grain economy, even when the natural forage is absent, it is rational to keep the cattle, and feed it on grain production withdrawals, as well as fodder grasses, which are the best forecrop for the winter wheat. Due to agriculture intensification the forage areas should be increased by 5.8 times. The main commercial crop is winter wheat. That is why application of the green-manured fallow (51\%) will protect soil from the erosion.

One of the zone characteristic features is high degree of the broken ground. When it is combined with high precipitation it causes water erosion. The main element of the agriculture system is erosion control methods.

\section{Conclusion}

1. The Stavropol Territory is the largest center of the grain farming in the South of Russia. Within agricultural goods production from 45 to $85 \%$ are occupied by crop production. There is profitability loss from $20.0--35.0 \%$, cost-push and quality loss of the crop production. This disbalance resulted in cattle breeding downswing. Such business situation leads land use to the branch of "subsidized survival" and unreasonably cost demanding and unstable agricultural goods production.

2. Modern agricultural activity in the Stavropol Territory is fulfilled at weak financial and state legal support and with the absence of exposure limits on the landscapes do not correspond to the existing natural-resource potential of the territory. Agriculture and AIC depend on weather-climatic and other natural and ecological conditions, state subsidizing and market situation.

3. The Stavropol territory is ecologically destabilized area. There is a negative balance of nutrients caused by reduction of fertilizers. In many parts of the tillage main agrochemical parameters decrease. Natural forage lands are in unsatisfactory condition in blockiness and their productivity does not meet the requirements of the cattle breeding.

4. Sustainable development of the agriculture in the region is possible at optimized structure-functional model of land utilization, where the optimal calculated crop land is $2.8 \mathrm{mln}$ ha. The crop area is $60.9 \%$ of the planted acreage (winter wheat -- $39.9 \%$ ), 
complete fallow -- $15 \%$, technical crops -- $14.2 \%$, potato, vegetable and gourd land -$3.4 \%$.

\section{References}

[1] Pehchukov, V.M., Dorozhko, G.R. (2005). Basics of agriculture in Stavropol. Stavropol: AGRUS.

[2] R'abov, I.E (2001). Influence of unfavorable weather conditions on the harvest and land resources in the Stavropol territory. Stavropol: Stavropol Publishing House.

[3] Zhuchenko, A.A., Trukhachev, V.V. Agriculture systems. Stavropol: AGRUS.

[4] Komov, N.V. (2004). Land use planning in land management: Agricultural regulation and land cadaster, $215 \mathrm{p}$.

[5] Khlystun, V.N. (2016). Effective land use as a successful factor of import substitution agriculture and processing enterprises economics, pp. 58--61.

[6] Pismennaya, E.V., Loshakov, A.V., Odinsov, S.V., Stukalo, V.A. Improving Model of Territorial Organization of Agricultural Land Tenure. Research Journal of Pharmaceutical, Biological and Chemical Sciences no. 7(6), pp. 1783--1787.

[7] Kashtanov, A.N. (1983). Agriculture sustainability: ways of improving. Moscow: Knowledge.

[8] Kalchenco, S., Yeremenko, D., Hrybova, D. (2018). Features of the use of resource potential in peasant farms. Baltic Journal of economic studies, no. 4(4), pp. 140--144.

[9] Voronin, B.A., Chupina, I.P., Sharapova, V.M. et al. (2017). Theoretical aspects of national food security provision issue. Turkish online journal of design art and communication, no. 7, pp. 2102--2108.

[10] Shulga, O. (2017). Patterns of development of relations of land ownership in the agrarian sector of the economy. Baltic Journal of economic studies, no. 3(4), pp. 307--318.

[11] Danilov-Danilian, V.I., Zalikhanov, M.Ch., Losev, K.S. (2007). Environmental safety. Common principles and Russian Aspect. Moscow: IICIA BIMPA.

[12] Rumina, E.V. (2000). Analysis of ecological-economical interactions. Moscow: Nauka.

[13] Zhuchenko, A.A. (2004). Resource potential for grain production in Russia (theory and practice). Moscow: LLC "Izdatel'stvo Agrorus".

[14] Dudych, H., Dudych, L. (2018). Assessment of the ecological sustainability of agricultural land use in the territorial structure of region. Scientific papers-series management economic engineering in agriculture and rural development, no. 18(4), pp. 87--92. 
[15] Podkovyrova, M., Kucherov, D., Ivanenko, V. (2019). Development of a Territorial Model of Agricultural Land Use on a Landscape-Ecological Basis. International journal of advanced biotechnology and research, no. 10(1), pp. 407--410.

[16] Sokolov, O.A. (2000). Agroecology. Moscow: RSAU.

[17] Wilson, C.O., Liang, B.R., Shannon, J. (2019). Projecting future land use/land cover by integrating drivers and plan prescriptions: the case for watershed applications. Giscience \& remote sensing, no. 56(4), pp. 511--535.

[18] Zhuchenko, A.A. (2004). Resource potential of grain production in Russia (theory and practice). Moscow: LLC "Izdatel'stvo Agrorus".

[19] Kirushin, V.I. (2010). Ecological sustainability of agricultural landscapes Issues of bioresources sustainability: theory and practice. Orenburg: Publishing House OSAU, pp. 6--14. 